\title{
QTL for resistance to summer mortality and OsHV-1 load in the Pacific oyster (Crassostrea gigas)
}

\author{
C. Sauvage ${ }^{1}$, P. Boudry ${ }^{2}$, D.-J. De Koning ${ }^{3}$, C. S. Haley ${ }^{3}$, S. Heurtebise ${ }^{1}$, S. Lapègue ${ }^{1, *}$ \\ 1 Ifremer, Laboratoire de Génétique et Pathologie, 17390, La Tremblade, France. \\ 2 Ifremer, UMR M100 Laboratoire de Physiologie et Ecophysiologie des Mollusques Marins, \\ Technopôle de Brest-Iroise, 29280 Plouzané, France. \\ ${ }^{3}$ Division of Genetics and Genomics, Roslin Institute and R(D)SVS, University of Edinburgh, Roslin \\ Biocentre, Midlothian EH25 9PS, Scotland, UK \\ *: Corresponding author : S. Lapègue, email address : Sylvie.Lapegue@ifremer.fr
}

\begin{abstract}
:
Summer mortality is a phenomenon severely affecting the aquaculture production of the Pacific oyster (Crassostrea gigas). Although its causal factors are complex, resistance to mortality has been described as a highly heritable trait, and several pathogens including the virus Ostreid Herpes virus type 1 (OsHV-1) have been associated with this phenomenon. A QTL analysis for survival of summer mortality and OsHV-1 load, estimated using real-time PCR, was performed using five $F_{2}$ full-sib families resulting from a divergent selection experiment for resistance to summer mortality. A consensus linkage map was built using 29 SNPs and 51 microsatellite markers. Five significant QTL were identified and assigned to linkage groups V, VI, VII and IX. Analysis of single full-sib families revealed differential QTL segregation between families. QTL for the two-recorded traits presented very similar locations, highlighting the interest of further study of their respective genetic controls. These QTL show substantial genetic variation in resistance to summer mortality, and present new opportunities for selection for resistance to OsHV-1.
\end{abstract}

Keywords: Crassostrea gigas; herpes virus; Pacific oyster; QTL mapping; summer mortality 


\section{Introduction}

The Pacific oyster, Crassostrea gigas, is one of the major aquacultured species with an annual worldwide production of 4.5 millions tons (FAO, 2006). However, several countries have encountered massive mortalities during the reproductive period (Goulletquer et al., 1998, Burge et al., 2006). This syndrome known as 'summer mortality' was described in Japan since the 1940s (Koganezawa, 1974) and it has been reported in many other countries (USA, Australia). In France, the Pacific oyster production has experienced periodic mass mortalities for at least 20 years (Renault et al., 1994; Soletchnik et al., 1999).

To better understand this phenomenon and propose solutions to reduce its impact on oyster production, a multidisciplinary project was conducted in France including studies on genetics, physiology, immunology and pathology (Samain and McCombie, 2007). Among pathogens, the Ostreid Herpes virus 1 (OsHV-1) has notably been detected during summer mortality outbreaks in France (Renault et al., 1994) and in the USA (Burge et al., 2007). A large additive genetic component was shown for survival from summer mortality of spat by divergent selection (estimated heritability $=0.70 \pm 0.28$; Dégremont et al., 2005) and this result was confirmed by a divergent selection experiment (realized heritability ranging from 0.64 to 0.82 according to sites, Boudry et al., 2008) However, even if the interest of developing a selective breeding program to improve this trait was clear (Boudry et al., 2008), two major challenges can be identified. Firstly, the trait itself (i.e. dead or alive after the summer period), although easy to record on large number of individuals or families, is highly dependant on field testing conditions and varies both spatially (between sites) and temporally (timing of placement on the field - Dégremont et al., 2005). Tight temporal monitoring of oysters is more difficult in tidal areas than in land-based tanks (Sauvage et al., 2009b). Secondly, the identification of the causal factors leading to mortality is essential to better understand and define the selected trait and therefore optimize its genetic improvement. This identification requires close individual monitoring of dying and surviving individuals to describe their physiological and immunological status, in relation to the eventual detection of pathogens. In this context, the identification of markers or, even better, genes associated with the genetic basis of resistance to summer mortality outbreaks are likely to contribute to the development of genetically improved oyster strains.

In recent years, genomic resources and tools have greatly increased notably in the Pacific oyster, with the development of more than 50.000 expressed sequenced tags (EST; Tanguy et al., 2008), the development of type II molecular markers (Yu and Li, 2008 ; Sauvage et al., 2009a) and the development of type I markers (Sauvage et al., 2007). Moreover, two linkage maps and a centromere map have been published in C. gigas (Li and Guo, 2004; Hubert and Hedgecock, 2004; Hubert et al., 2009). To date, no detailed QTL mapping study has been published using these maps. Microsatellites are particularly polymorphic in marine bivalves and are relatively easy to score (Sauvage et al., 2009a) and SNP markers are the most abundant molecular markers in most genomes (Brookes, 1999).

QTL have great potential for use in marker-assisted selection (MAS) for phenotypic traits such resistance to mortality and provide the basis for cloning the genes that underlies the genetic architecture of the traits. Clarification of the genetic bases of complex traits has broad implications for fundamental research, but will also be of practical benefit to aquaculture. This approach has been applied in many livestock species and has been introduce recently in aquacultured species such as in the rainbow trout, Oncorhynchus mykiss (Ozaki et al., 2001), the Atlantic salmon, Salmo salar (Houston et al., 2008) or in the Eastern oyster, Crassostrea virginica (Yu et Guo, 2006) to improve traits of economical interest such as the resistance to a disease. The aim of the present study was to identify QTLs for two traits in the Pacific oyster: mortality during a summer mortality outbreak and OsHV-1 load using real time PCR (Pépin et al., 2008; Sauvage et al., 2009b) in $F_{2}$ full-sibs families resulting from a divergent selection experiment (Boudry and Dégremont, 2008). 


\section{Materials and methods}

Biological material: The QTL population was created using divergently selected lines of oysters from the MOREST program (French multi-disciplinary project on summer mortalities in the Pacific oyster, Samain and McCombie, 2008). Briefly, in G0, two groups of half-sib families ("R" and "S") were selected on the basis of average summer survival of their progenies on the field (Dégremont et al., 2005). The two groups were used as progenitors to generate successive generations (G1, G2 and G3), following a divergent selective breeding design where inbreeding was avoided. For the QTL families, $F_{0}$ individuals were selected and sampled from the G3 generation of the MOREST program From the $F_{1}$, five full-sib $F_{2}$ families were produced (named 1 to 5 ).

Phenotyping: Monitoring of survival and OsHV-1 load is described in detail in Sauvage et al. (2009b). On the $5^{\text {th }}$ of July 2006 (i.e. prior to mortality outbreak), 96 individuals per family were sampled and checked by real time-PCR to evaluate the viral prevalence of OsHV-1. For each family, one thousand randomly sampled individuals were placed in bags and daily checked and sampled from day $138\left(8^{\text {th }}\right.$ of July 2006) to day 224 (October $15^{\text {th }}$ 2006). During the experiment, dead oysters (i.e. presenting permanently open valves) were collected daily and immediately frozen at $-20^{\circ} \mathrm{C}$ for subsequent DNA extraction. The monitoring ended after 86 days, when no mortality was observed after several weeks and the environmental conditions were unlikely to lead to further mortality. At the end of the experiment (day 224), 150 oysters per family that survived to the summer mortality period were sampled.

OsHV-1 DNA detection and quantification was performed on frozen material by real timePCR (Pépin et al., 2008) that enables both detection and quantification of viral DNA (as absolute number of copies or relative amount when normalized to DNA input or additional normalizing genes). The specificity of the PCR products was systematically controlled with the melting temperature (Tm) value from dissociation curve using a Mx3000P Q-PCR machine (Stratagene). The quantification of the samples was based on a standard five-fold dilution curve derived from a stock solution of OsHV-1 genomic DNA extracted from purified virus particles (Le Deuff and Renault, 1999).

Molecular markers and selective genotyping: In three $F_{2}$ families, 300 individuals from the extremes of the phenotypic distribution (150 dead and 150 surviving juveniles) were genotyped for type I markers whereas a subset of 96 (chosen randomly among the 150 individuals) were genotyped for type II markers. In total 900 individuals were genotyped. Because of the higher level of polymorphism, microsatellites were genotyped on the subset of 96 individuals reducing the costs and the genotyping effort. Total DNA was extracted using the Qiagen Qiamp ${ }^{\circledR}$ tissue mini kit (Robledo et al., 2000) according to the manufacturer's protocol, from mantle tissue. DNA qualities were visually checked to remove and replace samples showing degraded DNA.

The $20 \mathrm{~F}_{0}$ individuals were genotyped for a total of 114 previously described microsatellites markers (Huvet et al., 2000; Li et al., 2003; Yamtich et al., 2005; Yu and Li, 2007; Sauvage et al., 2009a) using a 3130 Applied Biosystems automatic sequencer (Applied Biosystems).

SNP markers were developed as described in Sauvage et al. (2007) and were genotyped using the MALDI-TOF mass spectrometry (Matrix-assisted laser desorption/ionization-time of flight, Griffin and Smith, 2000) on the Max Planck Institute genotyping platform in Berlin (Germany). Briefly, primers were designed using Primer 3 (Rozen and Skaletsky, 2000) in ESTs of interest related to summer mortality, identified through a SSH (Suppression Subtractive Hybridization approach, Fleury et al., 2009) or were selected from existing database such as GigasBase (http://www.ifremer.fr/GigasBase) and Genbank. In a second step, one informative locus per EST was chosen to be genotyped in the $F_{0}, F_{1}$ and $F_{2}$ individuals.

Data analyses: Phenotypes were either binary for survival (1, died; 0 , survived) or quantitative for OsHV-1 load (number of viral DNA copies/mg of fresh tissue). The normality of the quantitative data was investigated using a Shapiro-Wilk test and quantitative phenotype data were $\log _{10}$ transformed before analysis.. A Spearman correlation test was 
used to evaluate the correlation between the two studied traits. A $\mathrm{Chi}^{2}$ test was used to evaluate the Mendelian segregation distortion in the $F_{2}$ families.

Linkage between markers was evaluated using the 'twopoint' option in Crimap (Green et al., 1990). Linkage was considered a significant when LOD (Log of the Odd Ratio) scores, i.e. the likelihood of a linkage between two markers, was superior to 3, allowing to assemble markers in linkage groups (LG). Genetic distances (cM, Kosambi) were calculated using 'build' option and their most probable order was estimated with 'flipsn' option. Finally, 'chrompic' option was used to highlight putative genotyping errors. A consensus map was built and the genome length $\left(G_{e}\right)$ was estimated by the formula $N(N-1) X / K$, where $N$ is the number of markers, $X$ is the maximum interval between two adjacent markers, and $K$ is the number of marker pairs at an LOD score of 3.0 (Chakravarti et al., 1991). The observed genome length $\left(\mathrm{G}_{0}\right)$ was calculated according to Cervera et al. (2001). The genome coverage was determined by dividing $\mathrm{G}_{\mathrm{o}} / \mathrm{G}_{\mathrm{e}}$.

Linkage groups were named according to the published map by Hubert and Hedgecock (2004) to allow direct comparison. Mapchart (Voorrips, 2002) was used to provide a graphical representation of the maps.

QTL analysis was carried out with QTL Express (http://qtl.cap.ed.ac.uk/; Seaton et al., 2002), in the three families, using a large single full-sib analysis module with the following parameters (model (pat+mat), 1cM intervals, two traits). The chromosome-wide thresholds were calculated for each linkage group, using 1,000 permutations and the genome-wide threshold (Lander and Kruglyak 1995) was calculated by applying a Bonferroni correction to account for the analysis of multiple linkage groups (Knott et al., 1998). Confidence intervals for the QTL position were calculated for each linkage group where a putative QTL was detected using the bootstrapping approach with 1000 replicates to define 95\% confidence for each QTL position. The full-sib family analysis is a general model that can be used when large full-sib families are available to infer segregation of QTL from both parents. It makes no assumption that the QTL alleles are fixed in the original grandparental lines, but can benefit from the increased probability of parental QTL heterozygosity if the grandparental lines differ in their QTL allele frequencies. The QTL effects were interpreted as mean, paternal and maternal components. This allows for differences in QTL genotypes between the parents as well as potential parent-of-origin effects like genomic imprinting. The variation due to a QTL is a function of its effects and the allele frequencies (see Falconer and MacKay, 1996). The genetic variance is summarized as: $V g=2 p q[a+d(q-p)]^{2}+(2 p q d)^{2}$, where $a$ is the additive effect, $d$ is the dominance effect and $p$ is the frequency of increasing allele (with $q=1-p$ ). In F2 design, we assume that $p=q=0.5$. So, $V g$ becomes: $0.5 a^{2}+(0.5 d)^{2}$. The explained part of variance (EPV) of the QTL loci was deduced from the ratio $\mathrm{Vg} / \mathrm{Vp}$, where $\mathrm{Vp}$ is estimated from the total phenotypic variance of the data. In our case, the EPV of QTL linked to the mortality trait was not estimated due to the binary nature of the trait. Moreover, due to the selective genotyping strategy, unbiased values for QTL effects were roughly estimated as proposed by Darvasi and Soller (1992).

Results

Phenotyping : The detailed description of mortality and OsHV-1 load is described in Sauvage et al. (2009b). Prior to the monitoring period, no significant mortality was recorded during the larval and spat stages of life. Mortality began three days after the start of the experiment (day 141) and has affected families of oysters in varying degrees. The $F_{2}$ families 4 and 5 exhibited a very low mortality rate of $1.2 \%$ and $5 \%$, respectively, whereas cumulative mortality was estimated as 29.8, 39.3 and $67 \%$ in the families 1, 2 and 3 . As a result, families 4 and 5 were discarded from the QTL analysis because we hypothesized that QTL linked to summer mortality and viral load trait were not segregating in these two families. In the other families, mortality occurred very abruptly and on a very large scale. More than $60 \%$ of dead individuals were sampled during a single week.

Viral load measured by RT-PCR: Estimated number of copies of OsHV-1 DNA/mg of fresh tissue in the set of 96 randomly chosen individuals sampled on the $5^{\text {th }}$ of July was low (i.e. always below $1.10^{3}$ copies). Individual viral quantification was significantly different $(P<0.001)$ between dead and surviving individuals. In dead individuals, the viral load showed a high 
variance both within and between families $(P<0.001$ - Table 1$)$ where the highest level of infection was detected in family $3(Z=27.25, P<0.001)$. The lowest level of infection was observed in family 2 with a mean value of $2.02 \times 10^{6}$ copies. Moreover, the correlation between the level of mortality that occurred in the three families and the average level of infection by OsHV-1 appeared to be highly significant (Spearman's $(=0.338 ; \mathrm{P}<0.001)$. In surviving oysters, viral load was significantly different to the viral load detected in dead oysters $(P<0,01)$ while ranging from 0 to $2.3 \times 10^{3}$ copies in the family 1 , from 0 to $1.7 \times 10^{3}$ copies in the family 2 and finally from 0 to $2.8 \times 10^{2}$ copies in the family 3 .

Genotyping: A total of 114 previously published microsatellites markers were tested in the F0. Only 43\% (49/114) of microsatellites were genotyped in the F1 and F2 generation, the remaining being either monomorphic or giving complex banding patterns in the $F_{0}$ individuals. For type I markers, the estimated overall rate of success was $41 \%(61 / 149)$. This result may probably be due to the design of primers on splicing sites with the amplification of large insert during PCR. Within the three $F_{2}$ families, $77 \%(47 / 61)$ of the markers gave reliable results. A total number of 114 markers (67 microsatellites and 47 SNP) were combined to build a consensus linkage map.

Segregation of markers and linkage mapping: $\mathrm{Chi}^{2}$ tests revealed segregation distortion in the data $(P>0.05)$. Observed allelic proportions were not in Hardy-Weinberg equilibrium for $40 \%$ and $65 \%$ of type I and type II markers, respectively. This is partly a result of the selective mortality that occurred during the larvae stage of life. For each molecular marker, genotype data exhibiting the lowest level of distortion within each family were kept to build the linkage map. The consensus sex-averaged linkage map showed 10 LG (Fig. 1), in agreement with the haploid number of chromosomes of the species, and spanned $1016.5 \mathrm{cM}$ with an average spacing of $12.7 \mathrm{cM}$. Irresolvable mapping problems were encountered with 18 of the 47 SNP markers with 12 SNP markers showing mapping distances exceeding 50 cM while 6 SNP and 16 of the 67 microsatellites showed multiple significant linkages with markers belonging to different linkage groups. Finally 29 SNPs and 51 microsatellites were successfully mapped. The consensus linkage map comprises a total of 80 markers of which 79 segregated in all three F2 families (only one marker was not segregating in the three families). The estimated genome coverage was 73.6\%.

QTL detection: QTL showing significant F values were detected on LGV, LGVI, LG VII and LG IX (Table 2 - Fig. 2). In family 1, two different QTL on LGVI linked to resistance to the summer mortality trait were detected at 94cM (65-110) and 117cM (89-125) and one single QTL on LG VII at $92 \mathrm{cM}(80-100)$. QTL linked to viral load trait were detected roughly at the same position in the two LG (LGVI: 94 cM (70-115) and 118 (92-120); LG VII: 98 cM (82$100)$ ). In terms of effects, for the mortality trait, paternal effects ranged from $-0.237 \pm 0.034$ to $0.008 \pm 0.003$ and ranged from $-0.108 \pm 0.013$ to $0.008 \pm 0.001$ for the viral load trait. Maternal effects ranged from $-0.176 \pm 0.035$ to $-0.089 \pm 0.053$ for the mortality trait and ranged from $0.155 \pm 0.018$ to $-0.049 \pm 0.034$ for the viral load trait.

In the family 2, significant QTL linked to both traits were detected in LG V, VI and VII. In LGV, QTL linked to the two traits were positioned at 61 and $62 \mathrm{cM}$ and showed the same $95 \%$ confidence interval (42-80). In LG VI, two QTL were detected at 63cM (45-70) and $145 \mathrm{cM}$ (128-155) for the mortality trait and at 65cM (48-72) and 142cM (128-143) for the viral load trait. In this family, a significant QTL was detected in LG VII but only for the mortality trait. Its relative position was $94 \mathrm{cM}$ (89-98). Paternal and maternal effects were estimated to range respectively from $-0.03 \pm 0.021$ to $0.122 \pm 0.034$ and from $-0.173 \pm 0.04$ to $0.194 \pm 0.035$, for the mortality trait. For the viral load trait, paternal and maternal effects respectively ranged from $0.183 \pm 0.125$ to $0.138 \pm 0.063$ and from $-0.469 \pm 0.231$ to $-0.165 \pm 0.099$.

Finally, in the family 3 significant QTL loci were detected in LGIX and were positioned at 94cM (80-93) and 95cM (80-99) for the mortality and viral load traits. The paternal effects associated were estimated to $-0.091 \pm 0.043$ and $-0.441 \pm 0.202$ for the mortality and viral load traits whereas maternal effects for both traits were estimated to $-0.118 \pm 0.038$ and $0.253 \pm 0.179$. More detailed maternal, paternal and main components effects are given in Table 2. 
The total explained proportion of variance (EPV) for both traits was estimated to 0.412 and 0.378 for the mortality and viral load traits, respectively. Detailed EPV for each QTL locus are reported in Table 2.

\section{Discussion}

This study is the first to report the detection of QTL affecting resistance to summer mortality and viral load in the Pacific oyster $C$. gigas. The first study of marker - phenotype association in ostreidae was reported in the American cupped oyster, Crassostrea virginica (Yu and Guo, 2006). The studied phenotype was the resistance to two pathogens (MSX and Perkinsus marinus) that affect farming yields analysed by differences in alleles frequencies prior to and after infection. The present experiment, designed with a high frequency of sampling of dead oysters reared under identical environmental conditions throughout the life of the individual and especially during the mortality event, allowed $(i)$ the individual viral quantification, as a measure of the viral infection using RT-PCR and (ii) to perform a QTL detection using quantitative data. It should be noticed that the same approach was also applied in the European flat oyster Ostrea edulis, where several QTL linked to the resistance to a pathogen (Bonamia ostreae), were mapped using survival data (Lallias et al., 2009).

In our study, the analyses were based on a large single full-sib analysis and the results were interpreted as paternal and maternal components. These results supports evidence that QTL show parent-of-origin effects, which may be due to imprinting from the parental lines in the phenotypic expression of the progenies. However, these models could also reflect different QTL genotypes in the $F_{1}$ parents.

Significant evidence for the segregation of 5 QTL was found on 4 linkage groups in the 3 studied $F_{2}$ families. However, QTL positions were estimated with a moderate degree of accuracy in the average 95\% confidence interval. The relatively low number of markers that are mapped in C. gigas compared to other organisms is the major limitation of the present study, which is balanced by the effect of the QTL and their potential use in marker-assisted selection programs with the difference in survival rates between families. Another limitation in accuracy is the limited amount of recombination that can be observed within one family of 150 or 94 genotyped offspring. In our study, the high level of significance of the 5 QTL regions for both phenotypic traits appears very promising for future applications. The results strongly suggest that major-effect QTL may be involved in the resistance to summer mortality in C. gigas. Our results are congruent with previous ones published in the European flat oyster (Lallias et al., 2009) that report the identification of a small number of large effect QTL associated to a disease resistance trait (i.e. susceptibility to the parasite Bonamia ostrea). However, the QTL effect reported in the present study are over- estimated as a result of the selective genotyping that was performed and the so-called Beavis effect (for a review, see $\mathrm{Xu}, 2003$ ). Moreover, our results show a high level of heterozygosity for the QTL, which is relatively unusual for phenotypic traits such as mortality, partly due to the selection of families that showed a wide range in survival. In the aquaculture context, the intense culture (e.g. density, stress) of the animals may tend to exacerbate the effect of the viruses, which corroborates the large effect of the QTL. These observations are also congruent with previous ones reporting large QTL effect, notably in the Atlantic salmon, where QTL related to the resistance to IPN (Infectious Pancreatic Necrosis) were reported (Houston et al., 2008).

Using several families in our study was very useful to detect different segregating QTLs as highlighted by the results of the analysis of single full sib families. Lines of oysters are not fully homozygous and are not fixed for the traits of interest, which means that the high variance in the viral prevalence and survival rate between the 5 full-sib oysters may be inferred by their parental origin. The low level of mortality exhibited in the families 4 and 5 supports this result. Consequently, these two families were not included in our QTL analysis, hypothesizing that QTL linked to the resistance to summer mortality were not segregating in 
these families, even if they may be the more promising families for further breeding. Each group of oysters may be composed of individuals with different degrees of tolerance to the infection and may be differentially affected. This means that marker - QTL association and the associated linkage disequilibrium were generated at the family level and not at a higher level allowing us to detect several different QTLs.

Our study shows very similar location of QTLs linked the two studied traits. We can therefore hypothesize that the genetic architecture underlying these two traits are similar. However, we need to get a better understanding of the involvement of OsHV-1 in the summer mortality phenomenon to support this hypothesis. Additionally, the close relationship between viral load and mortality suggests a direct relationship between individual OsHV-1 load and mortality during our experiment (Sauvage et al., 2009b). However, this hypothesis should be interpreted with caution as no other pathogen (such as Vibrio bacteria) associated to the 'summer mortality' phenomenon was looked for.

Detection of OsHV-1 using PCR in some of these lines was performed at the larval and adult stages in successive generations under hatchery conditions (Barbosa-Solomieu et al., 2005). No significant differences were observed between " $R$ " and " $S$ " lines for survival at larval stage (Dégremont, 2003) neither for OsHV-1 prevalence (Barbosa-Solomieu et al., 2005). The susceptibility of these lines to OsHV-1 remains to be investigated because of the difficulties associated with experimental transmission of OsHV-1 after the larval stage (Le Deuff and Renault, 1999).

Although selective breeding is still limited for the Pacific oyster (for review see Boudry, 2009), the future application of QTL identification will be through implementation in breeding programs to initiate a marker-assisted selection (MAS). In many farmed species, there is still a contrast between the large number of papers reporting the identification of QTL and the limited number of cases where they have been applied. QTL must be validated in further studies before MAS is implemented because accurate estimates of QTL magnitude, position and effect are needed to optimize their use (Spelman and van Arendonk, 1997). However, in the Pacific oyster, before the implementation of the present results in MAS, the role of epistasis and genomic background in the genetic architecture of both traits should be assessed (Danzmann et al., 1999; Perry et al., 2003). Moreover, the identification of 'outlier QTL loci' in natural population may be of high interest in order to validate the QTL loci detected through QTL mapping experiment (Rogers and Bernatchez, 2005). As previously described, the relatively low number of markers that are mapped in $C$. gigas compared to other organisms is the major limitation of the present study. The development and the mapping of a higher number of genetic markers will increase the accuracy of the genetic map obtained, the power of detection of the QTL and the accuracy of the estimation of the QTL effects and their confidence interval. The recent increase of genomic resources in this species such as dedicated EST databases (Fleury et al., 2009), cDNA microarrays (Jenny et al., 2007), BAC libraries (Cunningham et al., 2006), and the current international efforts to sequence the whole genome of this species (Hedgecock et al., 2005; Zhang et al., 2008) will allow the development of large numbers of microsatellite and SNP markers, the integration of linkage and physical maps. Moreover, with an increased density of markers, QTL will be detected with a higher degree of accuracy and allow to narrow their confidence interval. Thus, the sequencing of BAC clones corresponding to the QTL loci will provide a list of candidate genes relying under the variance of the two studied traits. Moreover, further colocation of QTLs and candidate genes differentially expressed between sensitive and resistant lines (Fleury et al., in press) should contribute to better understand the complex genetic architecture between genes underlying the resistance to summer mortality in the Pacific oyster. 


\section{Acknowledgement}

The authors wish to thank the Ifremer hatchery and nursery teams in La Tremblade, Bouin and Argenton for their technical assistance during the larval and post-larval rearing. This work was supported by the European project "Aquafirst: Combined genetic and functional genomic approaches for stress and disease resistance marker assisted selection in fish and shellfish" (STREP contract $n^{\circ}$ 513692), the Network of Excellence "Marine Genomics Europe", the Région Poitou-Charentes (CPER) and the EU project Aquagenome "Genomics in fish and shellfish: From research to aquaculture". We also thank the three anonymous reviewers for the helpful input in their reviews of this paper.

\section{Literature cited}

Barbosa-Solomieu V., Degremont L., Vazquez-Juarez R., Ascencio-Valle F., Boudry P. and Renault, T. (2005). Ostreid Herpesvirus 1 (OsHV-1) detection among three successive generations of Pacific oysters (Crassostrea gigas). Virus Research 107(1): 47-56.

Boudry P. (2009) Genetic variation and selective breeding in hatchery-propagated molluscan shellfish, with special reference to oysters. In: New technologies in aquaculture: Improving production efficiency, quality and environmental management. Woodhead Publishing Limited, Cambridge, U.K.

Boudry P., Dégremont L., Haffray P. (2008). The genetic basis of summer mortality in Pacific oyster spat and potential for improving survival by selective breeding in France. In: Summer mortality of Pacific oyster Crassostrea gigas - The Morest Project. Quae Editions, Versailles, France, pp.153-196.

Brookes A. J. (1999). The essence of SNPs. Gene 234(2): 177-186.

Burge C. A., Griffin F. J. and Friedman, C. S. (2006). Mortality and herpesvirus infections of the Pacific oyster Crassostrea gigas in Tomales Bay, California, USA. Diseases of Aquatic Organisms 72(1): 31-43.

Burge C. A., Judah L. R., Conquest L. L., Griffin F. J., Cheney D. P., Suhrbier A., Vadopalas, B., Olin P. G., Renault T. and Friedman C. S. (2007). Summer seed: the influence of oyster stock, planting time, pathogens and environmental stressors. Journal of Shellfish Research 26(1): 163-172.

Chakravarti A., Lasher L. K. and Reefer J. E. (1991). A maximum likelihood method for estimating genome length using genetic linkage data. Genetics 128(1): 175-182.

Cervera M. T., Storme V. Ivens B., Gusmão J., Liu B. H., Hostyn V., Salyeken J. V., Montagu M. V., and Boerjan W. (2001). Dense genetic linkage maps of three Populus species (Populus deltoides, P. nigra and P. trichocarpa) based on AFLP and microsatellite markers. Genetics 158: 787-809

Cunningham C., Hikima J., Jenny M. J., Chapman R. W., Fang G. C., Saski C., Lundqvist M. L., Wing R. A., Cupit P. M., Gross P. S., Warr G. W. and Tomkins, J. P. (2006). New resources for marine genomics: bacterial artificial chromosome libraries for the Eastern and Pacific oysters (Crassostrea virginica and C. gigas). Marine Biotechnology (NY) 8(5): 521-33. Danzmann R. G., Jackson T. R. and Ferguson M. (1999). Epistasis in allelic expression at upper temperature tolerance QTL in rainbow trout. Aquaculture 173(1-4): 45-58.

Darvasi A. and Soller M. (1992). Selective genotyping for determination of linkage between a marker locus and a quantitative trait locus. Theoretical and Applied Genetics 85(2): 353-359.

Dégremont L. (2003). Etude des bases génétiques de la mortalité estivale et des relations avec la croissance chez les juvéniles de l'huître creuse Crassostrea gigas. Thèse de doctorat, Université de Caen - Basse Normandie: 333p.

Dégremont L., Bedier E., Soletchnik P., Ropert M., Huvet A., Moal J., Samain J.-F. and Boudry P. (2005). Relative importance of family, site, and field placement timing on survival, growth, and yield of hatchery-produced Pacific oyster spat (Crassostrea gigas). Aquaculture 249(1-4): 213-229. 
Dégremont L., Ernande B., Bedier E. and Boudry P. (2007). Summer mortality of hatcheryproduced Pacific oyster spat (Crassostrea gigas). I. Estimation of genetic parameters for survival and growth. Aquaculture 262(1): 41-53.

de Koning D. J., Rattink A. P., Harlizius B., van Arendonk J. A., Brascamp E. W. and Groenen M. A. (2000). Genome-wide scan for body composition in pigs reveals important role of imprinting. Proceedings of the National Academy of Sciences USA 97(14): 7947-50.

Falconer D. S. and Mackay T. F. C. (1996). Introduction to Quantitative Genetics. Essex, England., Longman Group Ltd.

Fleury E., Huvet A., Lelong C., de Lorgeril J., Boulo V., Gueguen Y., Bachere E., Tanguy A., Moraga D., Fabioux C., Lindeque P., Shaw J., Reinhardt R., Prunet P., Davey G., Lapegue S., Sauvage C., Corporeau C., Moal J., Gavory F., Wincker P., Moreews F., Klopp C., Mathieu M., Boudry P. and Favrel P. (2009). Generation and analysis of a 29,745 unique expressed sequence tags from the Pacific oyster (Crassostrea gigas) assembled into a publicly accessible database: the GigasDatabase. BMC Genomics 10(1): 341.

Fleury E., Moal J., Boulo V., Daniel J.-Y., Mazurais D., Hénaut A., Boudry P., Favrel P and Huvet $A$. Identification of new genes associated with summer mortality in the oyster Crassostrea gigas. Marine Biotechnology, in press.

Goulletquer P., Soletchnik P., Le Moine O., Razet D., Geairon P. and Faury, N. (1998). Summer mortality of the Pacific cupped oyster Crassostrea gigas in the Bay of MarennesOleron (France). Council Meeting of the International Council for the Exploration of the Sea. Cascais (Portugal).

Green P., Falls K. and Crooks S. (1990). Documentation for CRIMAP Version 2.4. Washington University School of Medicine, St Louis, MO, USA.

Griffin T. J. and Smith L. M. (2000). Single-nucleotide polymorphism analysis by MALDI-TOF mass spectrometry. Trends in Biotechnology 18(2): 77-84.

Hedgecock D., Gaffney P. M., Goulletquer P., Guo X. M., Reece K. and Warr G. W. (2005). The case for sequencing the Pacific oyster genome. Journal of Shellfish Research 24: 429441.

Houston R. D., Haley C. S., Hamilton A., Guy D. R., Tinch A. E., Taggart J. B., McAndrew B. J. and Bishop S. C. (2008). Major quantitative trait loci affect resistance to infectious pancreatic necrosis in Atlantic Salmon (Salmo salar). Genetics 178(2): 1109-1115.

Hubert S. and Hedgecock D. (2004). Linkage maps of microsatellite DNA markers for the Pacific oyster Crassostrea gigas. Genetics 168(1): 351-62.

Huvet A., Boudry P., Ohresser M., Delsert C. and Bonhomme F. (2000). Variable microsatellites in the Pacific oyster Crassostrea gigas and other cupped oyster species. Animal Genetics 31(1): 71-2.

Jenny M. J., Chapman R. W., Mancia A., Chen Y. A., McKillen D. J., Trent H., Lang P., Escoubas J. M., Bachere E., Boulo V., Liu Z. J., Gross P. S., Cunningham C., Cupit P. M., Tanguy A., Guo X., Moraga D., Boutet I., Huvet A., De Guise S., Almeida J. S. and Warr G. W. (2007). A cDNA microarray for Crassostrea virginica and C. gigas. Marine Biotechnology (NY) 9(5): 577-91.

Knott S. A., Marklund L., Haley C. S., Andersson K., Davies W., Ellegren H., Fredholm M., Hansson I., Hoyheim B., Lundstrom K., Moller M. and Andersson L. (1998). Multiple marker mapping of quantitative trait loci in a cross between outbred wild boar and large white pigs. Genetics 149(2): 1069-1080.

Koganezawa A. (1974). Present status of studies on the mass mortality of cultured oysters in Japan and its prevention. Proceedings of the Third U.S.-Japan Meeting on Aquaculture, Tokyo, Japan.

Lallias D., Gomez-Raya L., Haley C., Arzul I., Heurtebise S., Beaumont A., Boudry P. and Lapègue, S. (2009). Combining two-stage testing and interval mapping strategies to detect QTL for resistance to Bonamiosis in the European flat oyster Ostrea edulis. Marine Biotechnology 11(5):570-584.

Lander E. and Kruglyak L. (1995). Genetic dissection of complex traits: guidelines for interpreting and reporting linkage results. Nature Genetics 11(3): 241-247. 
Le Deuff R. M. and Renault T. (1999). Purification and partial genome characterization of a herpes-like virus infecting the Japanese oyster, Crassostrea gigas. Journal of General Virology 80: 1317-1322.

Li G., Hubert S., Bucklin K., Ribes V. and Hedgecock D. (2003). Characterization of 79 microsatellites DNA markers in the Pacific oyster Crassostrea gigas. Molecular Ecology Notes 3(2): 228-232.

Li L. and Guo X. (2004). AFLP-based genetic linkage maps of the pacific oyster Crassostrea gigas (Thunberg, 1793). Marine Biotechnology 6(1): 26-36.

Moen T., Fjalestad K.T., Munck H. and Gomez-Raya L. (2004). A multistage testing strategy for detection of quantitative trait Loci affecting disease resistance in Atlantic salmon. Genetics 167:851-858

Ozaki A., Sakamoto T., Khoo S., Nakamura K., Coimbra M., Akutsu, T. and Okamoto N. (2001). Quantitative trait loci (QTLs) associated with resistance/susceptibility to infectious pancreatic necrosis virus (IPNV) in rainbow trout (Oncorhynchus mykiss). Molecular genetics and Genomics 265(1): 23-31.

Pépin J.-F., Riou A. and Renault T. (2008). Rapid and sensitive detection of ostreid herpesvirus 1 in oyster samples by realtime PCR. Journal of Virological Methods 149(2): 269-276.

Perry G. M. L., Ferguson M. M. and Danzmann R. G. (2003). Effects of genetic sex and genomic background on epistasis in rainbow trout (Oncorhynchus mykiss). Genetica 119(1): 35-50.

Renault T., Cochennec N., Le Deuff R. M. and Chollet B. (1994). Herpes-like virus infecting Japanese oyster (Crassostrea gigas) spat. Bulletin of European Association of Fish Pathology 14: 64-66.

Robledo J. A. F., Pecher W. T. and Vasta G. R. (2000). High-throughput isolation of oyster DNA facilitates diagnosis of "Dermo" disease. Qiagen News 5: 15-17.

Rogers S. M. and Bernatchez L. (2005). Integrating QTL mapping and genome scans towards the characterization of candidate loci under parallel selection in the lake whitefish (Coregonus clupeaformis). Molecular Ecology 14(2): 351-361.

Rozen S. and Skaletsky H. (2000). Primer3 on the WWW for general users and for biologist programmers. Methods Molecular Biology 132: 365-86.

Samain J.F., McCombie H. (2008). Summer mortality of Pacific oyster Crassostrea gigas. The Morest Project. Quae ed., Versailles, France..

Samain J. F., Ropert M., Bédier E., Soletchnik P., Mazurié J., Le Coz F., Blin J. L., Costil K., Mille D., Trintignac P., Boudry P., Haffray P., Bacher C., Grangeré K., Pouvreau S., Bourles Y., Sylvand B., Misko P., Gohin F. and Woerther P. (2007). Le facteur risque Température. In: Mortalités estivales de I'huître creuse Crassostrea gigas. Défi Morest. Ed. Ifremer/Quæ: 291-331.

Sauvage C., Bierne N., Lapegue S. and Boudry P. (2007). Single Nucleotide polymorphisms and their relationship to codon usage bias in the Pacific oyster Crassostrea gigas. Gene 406(1-2): 13-22.

Sauvage C., Boudry P. and Lapègue S. (2009a). Identification and characterization of 18 novel polymorphic microsatellite makers derived from expressed sequence tags in the Pacific oyster Crassostrea gigas. Molecular Ecology Notes 9(3): 853-855

Sauvage C., Pépin J. F., Lapègue S., Boudry P. and Renault T. (2009b). Ostreid herpes virus 1 infection in families of the Pacific oyster, Crassostrea gigas, during a summer mortality outbreak: differences in viral DNA detection and quantification using real-time PCR. Virus research 14: 181-187.

Seaton G., Haley C. S., Knott S. A., Kearsey M. and Visscher P. M. (2002). QTL Express: mapping quantitative trait loci in simple and complex pedigrees. Bioinformatics 18; 339-340.

Soletchnik P., Le Moine O., Faury N., Razet D., Geairon P. and Goulletquer P. (1999). Mortalité de l'huître Crassostrea gigas dans le bassin de Marennes-Oléron. Etude de la variabilité spatiale, de son environnement et de sa biologie par un système d'information géographique (SIG). Aquatic Living Resources 12(2): 131-143. 
Sonesson A.K. (2007) Possibilities for marker-assisted selection in aquaculture breeding schemes. In: Guimarães, E., Ruane, J., Scherf, B., Sonnino, A. and Dargie, J. (eds) Markerassisted selection: Current status and future application in crops, livestock, forestry, and fish. FAO, Rome, pp. 309-328.

Spelman R. J. and van Arendonk J. A. M. (1997). Effect of inaccurate parameter estimates on genetic response to marker-assisted selection in an outbred population. Journal of Dairy Science 80(12): 3399-3410.

Tanguy A., Bierne N., Saavedra C., Pina B., Bachere E., Kube M., Bazin E., Bonhomme F., Boudry P., Boulo V., Boutet I., Cancela L., Dossat C., Favrel P., Huvet A., Jarque S., Jollivet D., Klages S., Lapegue S., Leite R., Moal J., Moraga D., Reinhardt R., Samain J.-F., Zouros E. and Canario A. (2008). Increasing genomic information in bivalves through new EST collections in four species: Development of new genetic markers for environmental studies and genome evolution. Gene 408(1-2): 27-36.

Visscher P. M., Thompson R. and Haley C. S. (1996). Confidence intervals in QTL mapping by bootstrapping. Genetics 143(2): 1013-20.

Voorrips R. E. (2002). MapChart: Software for the graphical resentation of linkage maps and QTLs. Journal of Heredity 93(1): 77-78.

Xu S. (2003). Theoretical Basis of the Beavis Effect. Genetics 165(4): 2259-2268.

Yamtich J., Voigt M. L., Li G. and Hedgecock D. (2005). Eight microsatellite loci for the Pacific oyster Crassostrea gigas. Animal Genetics 36(6): 524-526.

$\mathrm{Yu}$ Z. and Guo X. (2006). Identification and mapping of disease-resistance QTLs in the eastern oyster, Crassostrea virginica Gmelin. Aquaculture 254: 160-170.

$\mathrm{Yu} \mathrm{H}$. and Li Q. I. (2007). EST-SSR markers from the Pacific oyster, Crassostrea gigas. Molecular Ecology Notes 7(5): 860-862.

$\mathrm{Yu} \mathrm{H}$. and Li Q. (2008). Exploiting EST databases for the development and characterization of EST-SSRs in the Pacific oyster (Crassostrea gigas). Journal of Heredity 99: 208-214.

Zhang G., Guo X., Li L., Xu F., Qi H., Song L., Liu X., Liu B., Que H., Liu B., Cheng P., Wu Q., Zhang L., Wang S., Wu H., Wang S., Wang J., Li R., Bao Z., Li Q., Yu Z., Zhang R., Hedgecock D. and Gaffney P.M. The Oyster Genome Project - the first for an aquaculture species in China. Procceedings of the 2008 International Conference on Genomics Applications in Asia-Pacific, November 2-5, 2008, Shenzhen \& Hong Kong, China. 
Table 1. Descriptive statistics of the viral load measured in the dead and survived individuals and expressed as a number of viral DNA copies number/mg of fresh tissue

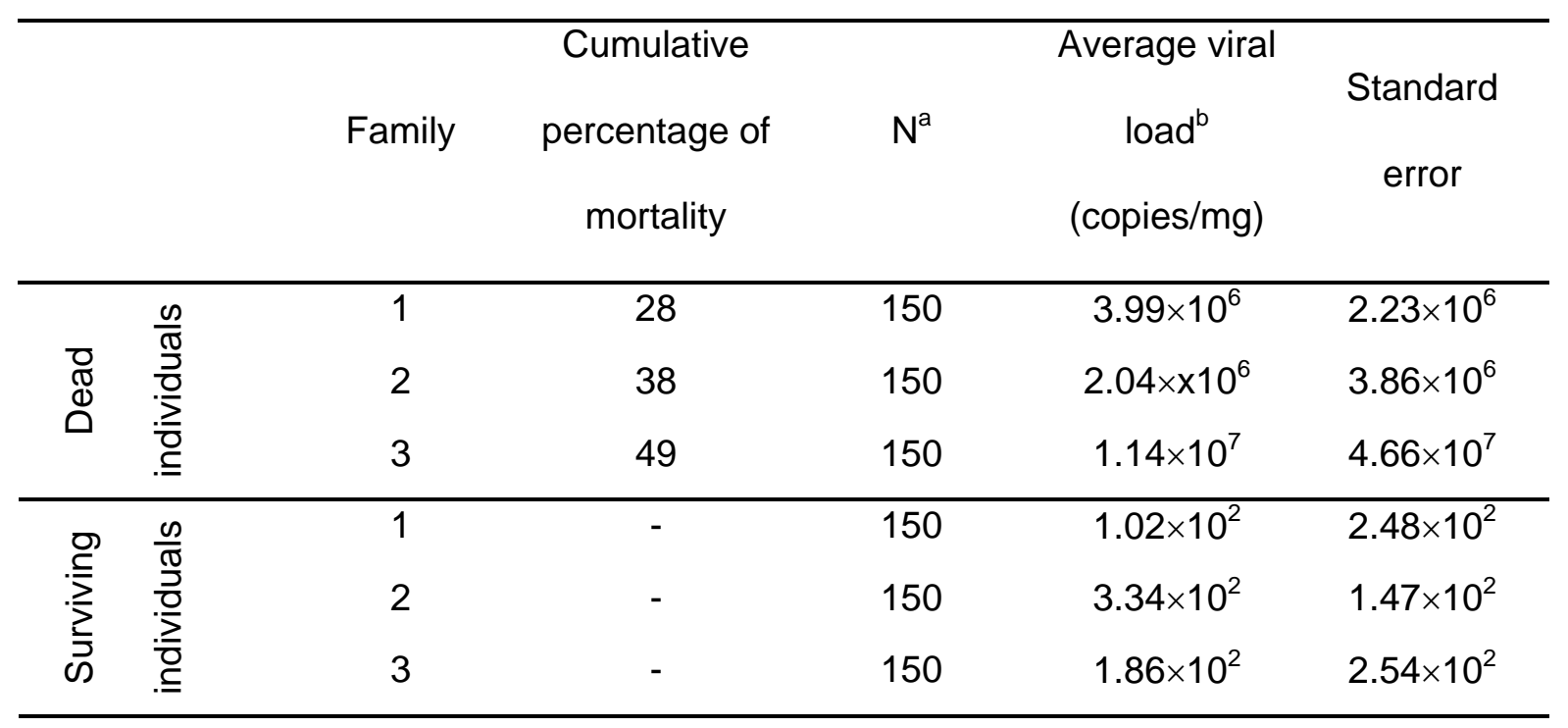

${ }^{a} \mathrm{~N}$ - Number of individuals analysed by Q-PCR

${ }^{\mathrm{b}}$ OsHV-1 viral load is expressed as a number of particles per mg of fresh tissue 
Table 2. Linkage groups containing QTLs significant for mortality and viral load for the three F2 families and the associated main, paternal and maternal effects

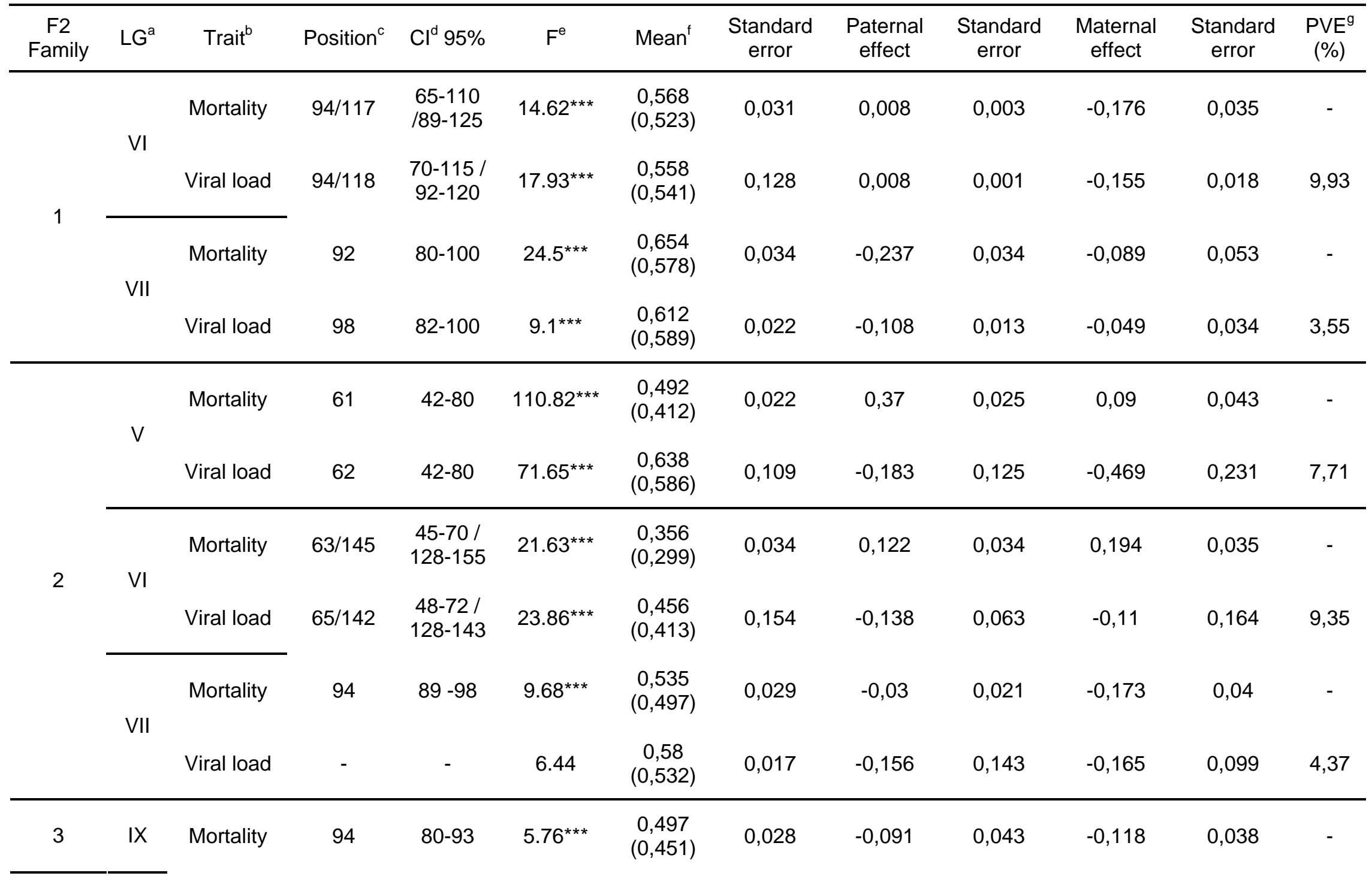




\begin{tabular}{lllllllll}
\hline Viral load $\quad 95$ & $80-99$ & $5.44^{* * *}$ & 0,563 & $(0,512)$ & 0,134 & $-0,441$ & 0,202 & $-0,253$ \\
\hline
\end{tabular}

a Linkage group nomenclature from Hubert and Hedgecock

(2004)

${ }^{\mathrm{b}}$ Phenotypes

c Average position of the

QTL

${ }^{\mathrm{d}}$ Confidence interval estimated by bootstrapping

e F-test with chromosomewide criterion of significance $\left({ }^{\star *} \mathrm{P}<0.001\right)$ using permutation test with re-sampling in $\mathrm{QTL}$ express with 1000 permutations followed by a Bonferroni correction based on the number and size of linkage groups.

${ }^{f}$ Mean effect of the QTL. Unbiased estimation of the QTL effect are figured between brackets

${ }^{\mathrm{g}}$ Part of the Variance Explained by the QTL 


\section{Figures}

Figure 1.- The consensus linkage map, based on the analysis of the three F2 families, is composed of 10 LG, includes 80 markers and spans $1016.5 \mathrm{cM}$. Linkage groups were named as their homolog in the map published by Hubert and Hedgecock (2004).

Figure 2.- QTL graphs with their respective 95\% confidence interval in linkage groups $\mathrm{V}, \mathrm{VI}$, VII and IX. Solid lines represent QTL $F$ ratio values for the mortality trait whereas dot lines represent $F$ ratio values for the OsHV-1 viral load trait. Constant dot lines represent the level of significance calculated at the chromosome-wide significance threshold. 


\section{Linkage Group}

LGV

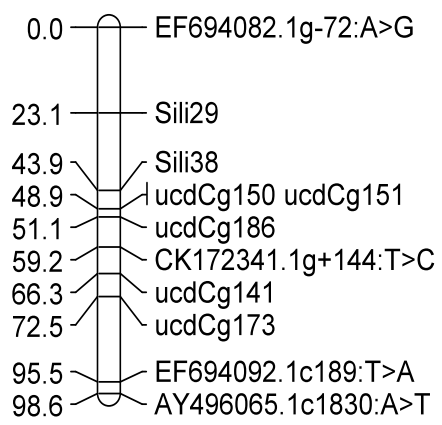

LGVI

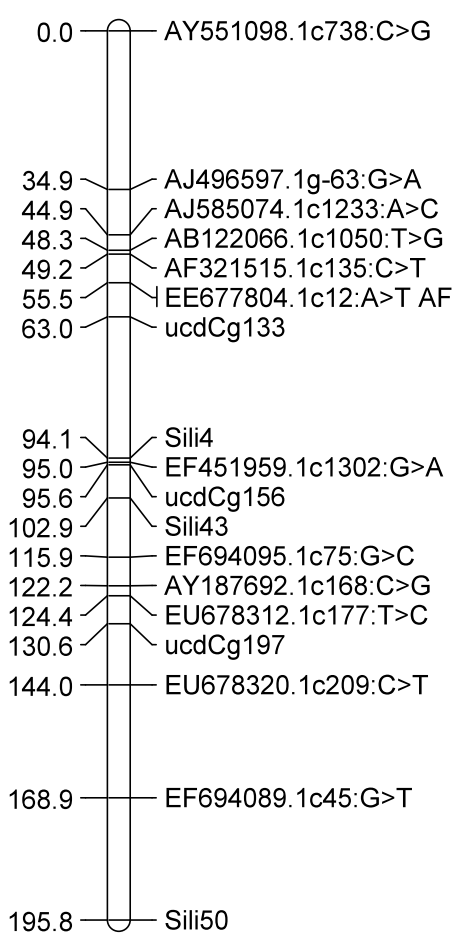

\section{LGVII}

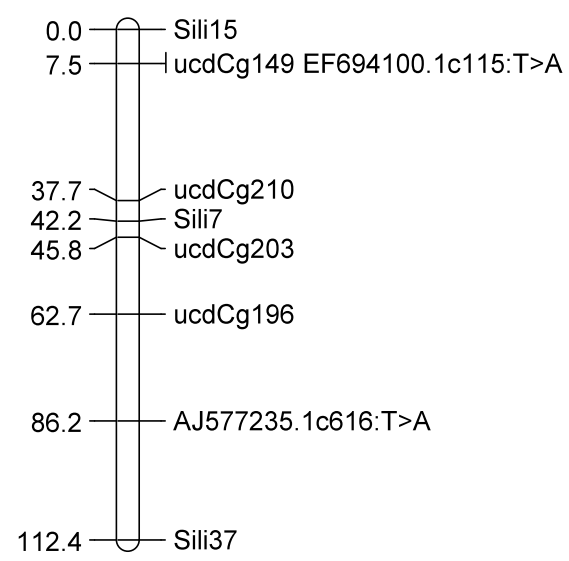

\section{F2 Families}

1

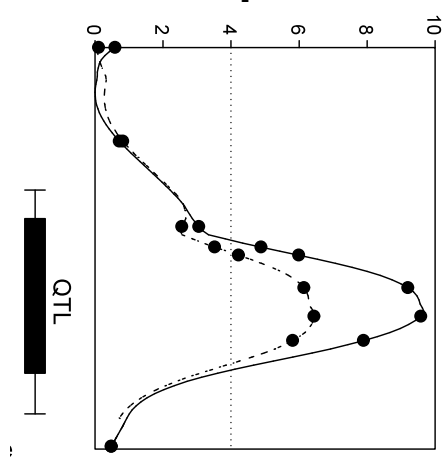

2
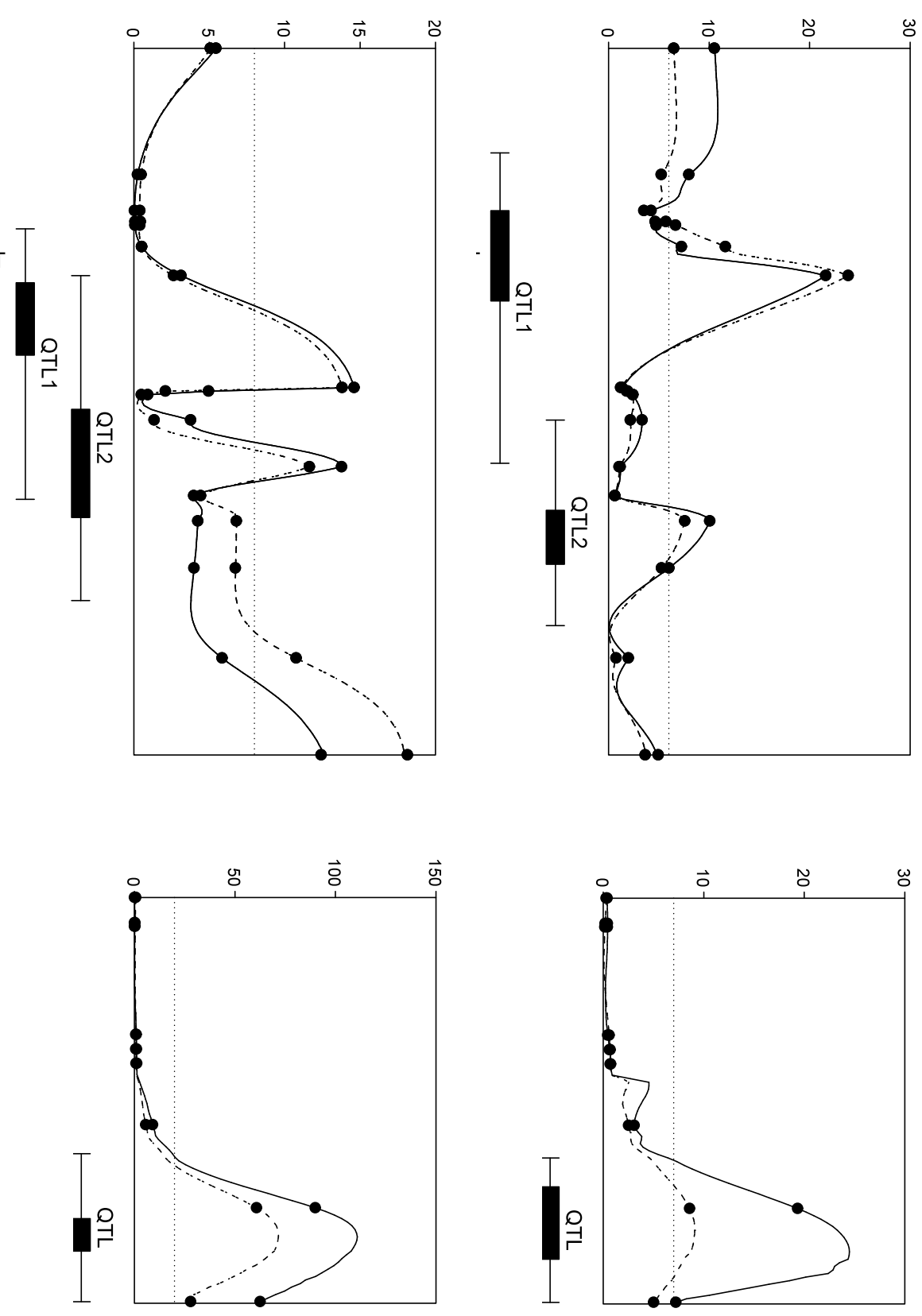


\section{Linkage Group}

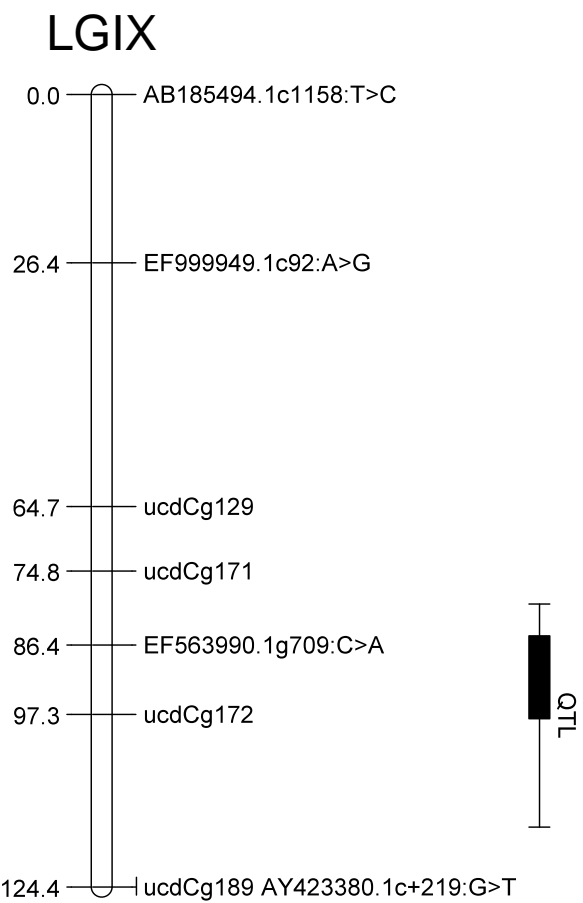

F2 Families

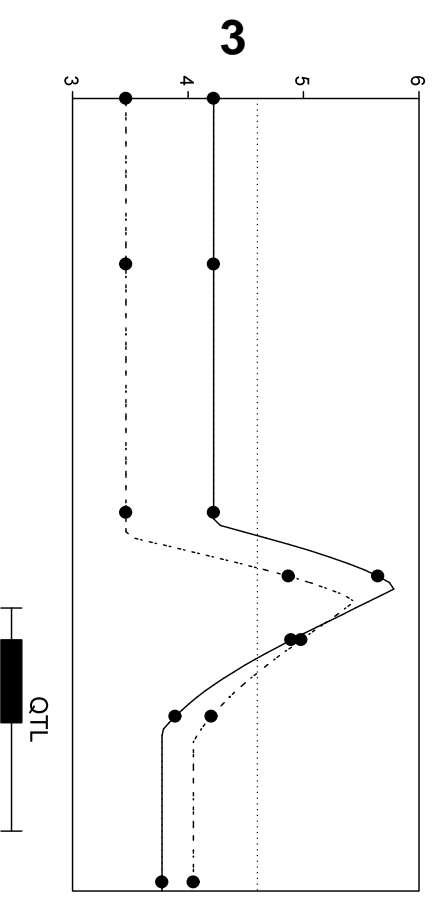

